\title{
Liquid egg products characterization during storage as a response of novel phyto-additives added in hens diet
}

\author{
Tatiana Dumitra Panaite ${ }^{1}$, Silvia Mironeasa ${ }^{2 *}$, Mădălina luga ${ }^{2}$, Petru Alexandru Vlaicu1 \\ ${ }^{1}$ National Research and Development Institute for Animal Biology and Nutrition (IBNA), Romania, ${ }^{2}$ Ştefan cel Mare University, Faculty of Food \\ Engineering, Str. Universităţi nr. 13, 720229, Suceava, Romania
}

\section{A B S T R A C T}

\begin{abstract}
This study aims to assess the effect of novel phyto-additives (bilberry leaves, walnut leaves, sea-buckthorn pomace and a mix of bilberry leaves, walnut leaves and sea-buckthorn pomace) added in hens diet on the liquid egg components (egg albumen, egg yolk and whole liquid egg) during storage. The phyto-additives added to the basic feed remarkably affected almost all the characteristics investigated, colour, $\mathrm{pH}$ and rheological behaviour of liquid egg products. The changes of egg yolk and albumen's colour and $\mathrm{pH}$ were not uniform. The supplementation of feeding with walnut leaves decreases significantly $(p<0.01)$ the luminosity of egg yolk, whereas the luminosity of egg albumen increases compared to the control. The $\mathrm{pH}$ values were influenced by the type of phyto-additive added in the hens diet, but its variations were only slightly dependent on the storage time of eggs. The rheological properties showed a pseudoplasticity of egg components depending on the hens diet and egg storage time. Ostwald-de Waele model fitted well with the rheological data, offering information on the changes of the apparent viscosity in relation to the diet type and storage time. The results indicated that these novel phyto-additives could be incorporated in hens diet for production of improved eggs quality and walnut leaves having a remarkable effect.
\end{abstract}

Keywords: Colour parameters; Eggs; pH; Phyto-additives; Rheological properties

\section{INTRODUCTION}

Eggs, known as unique food material, represent a rich source in high-quality proteins, unsaturated fatty acids, phospholipids, minerals, vitamins and lipophilic pigments including antioxidant carotenoids (Huopalahti et al., 2007). After breaking the shell, the basic components obtained are egg albumen which portion makes up $60 \%$ of the egg's weight and yolk egg that represents approximately $35 \%$ of the liquid egg. The albumen and yolk egg have many functional properties which mainly depend on the quality of their proteins (Mine, 2002). As multifunctional food materials, due to their nutritional and functional properties, eggs are incorporated in various food systems, increasing their nutritional value, improving color and flavor. Egg is used as ingredient in bakeries, biscuits, pasta e.g., (Stadelmann and Cotterill, 1995). In recent years, egg consumption in the form of egg components has increased compared to marketed shell eggs (Jesús et al., 2013). The egg components characteristics such as colour, $\mathrm{pH}$ and viscosity are influenced by the diet administered to laying hens (Lomakina and Mikova, 2006). The carotenoids, particularly lutein and zeaxanthin and xanthophylls with their antioxidant effects influenced the colour of egg yolk (Kopriva et al., 2014). Also, the housing system has a significant effect on the yolk colour (Sokołowicz et al., 2018).The $\mathrm{pH}$ affected the thinning of the thick albumen (Burley and Vadehra 1989; Kato et al., 1970) and is being used to assess thick albumen thinning (Beveridge and Nakai, 1975). The viscosity depends also on the storage time and temperature, water content and egg stress.

Several tests have been made to reestablish the egg consumption by modifying egg composition through feeding nutritionally-changed diets. The supplementations of the hens diet with phytonutrients can remarkable affect on the quality of eggs (Nour et al., 2018; Dvořák et al., 2017). Several reports have described the effect of different feed additives in laying hens fed diet on egg quality (Świątkiewicz et al., 2018; Arpášová et al., 2012). The phytochemicals, like phenolic compounds, are considered beneficial for both human and animal health (Silva et al., 2006).

\footnotetext{
*Corresponding author:

Silvia Mironeasa, Ştefan cel Mare University, Faculty of Food Engineering, Str. Universităţii nr. 13, 720229, Suceava, Romania.

Tel: + 40230216 147; + 40741985 648. E-mail: silviam@fia.usv.ro; silvia_2007_miro@yahoo.com
}

Received: 11 February 2019; Accepted: 22 April 2019 
Supplementation of the feed diet with bilberry leaves, walnut leaves and sea-buckthorn pomace a to laying hens could modify components of the edible part of eggs, leading to properties favorable to consumers. Bilberry leaves contain high levels of phenolic compounds (Martz et al., 2010). The phenolic compounds content of bilberry leaves depends on the harvest period (Ieri et al., 2013). Bilberry leves can be used as antibacterial, anti-inflammatory, being also helpful in cancer prevention (Mechikova et al., 2010). Walnut leaves are a good source of phenolic compounds (Pereira et al., 2007). The walnut leaves contain high amounts of antioxidants. The most important component is represented by the elagic acid which has anti-cancer effects (Nour et al., 2012). Due to their high antioxidant potential bilberry leaves and walnut leaves could be useful in diseases prevention in which free radicals are implicated. Sea-buckthorn pomace is a valuable by-product which contains high amounts of valuable vitamins, flavonoids and fatty acids. The lipid fraction of sea-buckthorn contains an average of $6-13 \% \alpha$-linolenic acid and has a low ratio of $n-6 / n-3$ polyunsaturated fatty acids of $1.1-1.3$ and a high concentration of monounsaturated fatty acids (49-52\%) (Nuernberg et al., 2015). Sea-buckthorn pomace is valued for its antioxidant properties because of its bioactive substances content (Korekar et al., 2011).

After laying, during storage, eggs components properties are significantly influenced by their storage condition mainly in a time and temperature dependent way (Chung et al., 2014). The changes are complex and affect the functional properties of liquid egg components, albumen, yolk and whole liquid egg. Modifications in the structure of protein can affect the rheological behavior of egg components. In fact, the rheological properties are usually influences by the $\mathrm{pH}$ value of liquid egg components. The rheological properties of liquid egg components are remarkable related with their flow transport and rheological properties are connected with continuous thermal processing system. Some of these problems are described by Souza and Fernandez (2013) and Cabral et al. (2011).

The use of liquid egg components in food industry needs rigorous knowledge of their rheological behaviour (Velez-Ruiz, 2002). Egg components viscosity influences a number of their functional and technological properties such as whipping, emulsifying and gelling ability (Kemps et al., 2010; Atílgan and Unluturk, 2008). Most of the studies have been frequently carried out with only egg yolk (Simeonovova et al., 2003). There is a lack of information about the rheological properties of liquid egg albumen and whole liquid egg.

This study aimed to investigate if the addition of novelty phytoadditives to laying hens feed affects liquid egg components
$\mathrm{pH}$, colour and whether the addition of phyto-additives to the diet of laying hens affects the rheological properties of liquid egg components, yolk, albumen and whole egg.

\section{MATERIALS AND METHODS}

\section{Experimental design}

The research was conducted on liquid egg components of egg-laying breeds which were fed 4 weeks with a diet enriched with some phyto-additives. The experiment was performed on 168140 Tetra SL laying hens (32 week old) which were housed in identical conditions, at temperature of $23.08 \pm 0.98^{\circ} \mathrm{C}$, moisture of $66.35 \pm 5.68 \%$ and ventilation/head/hen of $1.70 \pm 0.14 \%$. Lighting was provided for $16 \mathrm{~h}$ of the $24 \mathrm{~h}$. Laying hens individually weighed were randomly divided into five experimental groups (C, E1, E2, E3 and E4). The groups of hens were reared in cages ( 2 hens/cage; 14 cages/experimental group) structured by three levels, with ad libitum access to feed and water. For the elaboration of the combined feed formulations used in this experiment, we considered the objective of the experiment, the species, the hybrid, the age and the nutritional requirements of the hybrid Tetra SL laying hens (Tetra-SL LL commercial Layer Management Guide, 2007). Control group (C) consumed a complete feeding mixture without the addition of phyto-additives, while the other four groups consumed a complete feeding mixture with phyto-additives such as, bilberry leaves (E1), walnut leaves (E2), sea-buckthorn pomace (E3) and, mix of bay bilberry leaves, sea-buckthorn pomace and walnut leaves, in equal proportions (E4). Water was administered using automatic feeders. The basic structure of fodder recipes was the same for all five experimental groups, characterized by $2800 \mathrm{kcal} / \mathrm{kg}$ metabolizable energy, $17.8 \%$ crude protein, $2.98 \%$ crude fat, $3.90 \%$ calcium, $0.78 \%$ lysine, $0.44 \%$ methionine and a ratio of the metabolizable energy/crude protein at a value of 157.30 .

A total of 12 eggs were collected from each hens group after a 4-week experimental period to evaluate the quality parameters of the liquid egg components. The selected eggs were subsequently stored under temperature of $5^{\circ} \mathrm{C}$ in unchangeable conditions for a period of one, 2, 3 and 4 weeks. Every time the liquid eggs components were obtained after eggshells were washed with deionized water and hand broken properly. The albumen and yolk were separated, filtered by colander in order to separate chaladza and other membranous impurities from egg yolk, and to eliminate foam formation in egg albumen.

\section{pH measurement}

The $\mathrm{pH}$ change of liquid egg components, in terms of egg albumen, egg yolk and whole liquid egg was performed 
using a HQ30d Portable pH Meter (HACK, Germany). Buffer solutions of $\mathrm{pH} 7$ and $\mathrm{pH} 4$ are used for calibration of $\mathrm{pH}$ meter. All measurements were carried out in triplicate.

\section{Colour egg components measurement}

The egg yolk, separated from the egg white prior to measurement, was placed on a Petri dish with a diameter of $50 \mathrm{~mm}$. Color analysis was performed using a Konica Minolta CR-400 colorimeter. The color parameters of $L^{*}$ (lightness), $a^{*}$ (red-green intensity) and $b^{*}$ (yellowblue intensity) of the CIE-Lab system (Commission Internationale de l'Eclaraige) were determined by reflectance CIE - $L^{*} a^{*} b^{*}$ colour coordinates. The total color difference $\left(\Delta E^{*}\right)$ were calculated as function of deviation from $L^{*}\left(\Delta L^{*}\right), a^{*}\left(\Delta a^{*}\right)$ and $b^{*}\left(\Delta b^{*}\right)$ by the Equation 1:

$$
\Delta \mathrm{e}^{*}=\left(\Delta \mathrm{a}^{* 2}+\Delta \mathrm{b}^{* 2}+\Delta \mathrm{L}^{* 2}\right)^{1 / 2}
$$

The instrument was calibrated with a white calibration before the measurements. All measurements were performed in triplicate.

\section{Rheological measurements}

The rheological measurements of the liquid egg components, in terms of liquid egg yolk, liquid egg albumen and liquid whole egg were carried out using a Haake MARS 40 dynamic rheometer (Thermo Haake Mars, Germany) equipped with a concentric cylinder measurement system (CC 25, $25 \mathrm{~mm}$ in diameter, $16.1 \mathrm{~mL}$ measuring cell). The flow curves was obtained by increasing shear rate from 0 to $100 \mathrm{~s}^{-1}$ The variation of sample apparent viscosity $\eta$ which is the ratio of shear stress $\tau$ and shear rate (Eq. 2) (Steffe 1996) was evaluated in the same analysis interval.

$$
\eta=\frac{\sigma}{\gamma}[\mathrm{Pa} \mathrm{s}]
$$

Ostwald-de Waele rheological model was adjusted to the shear stress - shear rate curve of each sample, in order to determine if the model fits better to the rheological properties of liquid egg components. The RheoWin 4 Data Manager software (version 4.20, Haake) was used for parameters calculations.

The mean calculated from the three measured values was used for further evaluation. All measurements were performed at room temperature $\left(20 \pm 1^{\circ} \mathrm{C}\right)$.

\section{Data analysis}

All data were statistically processed for each quality parameters of the liquid egg components. Analysis of variance (ANOVA) was applied to test the dependence of liquid egg components quality parameters on the addition of phyto-aditives in a feedings dose. The dependence of the feeding of laying hens and eggs storage duration on the evaluated quality parameters were tested using twofactor ANOVA. The level of significance was selected at $p<0.05$. For viscosity curve fitting of the experimental data a RheoWin 4 Data Manager software (version 4.20, Haake) was used. The suitability of the fitted model was evaluated by the coefficient of determination $\left(R^{2}\right)$.

\section{RESULTS AND DISCUSSION}

\section{Effect of hens diet and egg storage time on colour parameters of liquid egg components}

The colour of liquid egg components was represented by $L^{*}, a^{*} b^{*}$ and $\Delta E^{*}$ values. Table 1 shows the colour parameters of the egg albumen. Luminosity, $L^{*}$ was more variable, decreasing or increasing in samples as function of type of phyto-additives added in hens diet.

A high increase of lightness was obtained in E3 and E2 samples when the feeding was supplemented with seabuckthorn pomace and respectively, walnut leaves. The high increase of lightness in E3 and E2 samples can be related to the compounds from sea-bucktorn pomace and for walnut leaves, such as lutein and zeaxanthin. Lutein, a yellow-orange color pigments, has been used for many years in poultry diets as a mean to pigment egg yolks (Wu et al., 2009). Redness of albumen is given by $a^{*}$ value, while $b^{*}$ values suggest the yellowness of albumen. Values of $a^{*}$ and $b^{*}$ parameters decrease significantly $(p<0.05)$ in the experimental groups E1, E2, E3 and E4, when the phyto-additives were added in hens diet, compared with the control. With the storage time increase, there was a significant decrease of $L^{*}$ and an increase of $a^{*}$, meaning lower lightness and higher redness of albumen. The total colour difference $\left(\Delta E^{*}\right)$ is higher for E2 (12.22) and E3 (12.64), as compared to the control group. The values obtained are very similar to those reported by Dvořák et al., (2012) for pastured laying hens. The increase of $\Delta E^{*}$ with the addition of walnut leaves (E2) and seabuckthorn pomace (E3) indicated the darker color of albumen which can be due to some bioactive substances and/or natural pigments from these phyto-additives known as xanthophylls.

The average changes of yolk colour as function of diet type of group and during storage is shown in Table 2. The addition of bilberry leaves in feeding caused a significant decrease only in value $a^{*}$, the $b^{*}$ suggesting the yellowness of yolk. This effect may be explained by the active constituents from bilberry leaves, such as quercetin, catechins, tannins and acids which can lead to the yellowness of yolk. A significant decrease $(p<0.05)$ 
Panaite, et al.

Table 1:Colour parameters of the liquid egg albumen in relation to the phyto-additives added in hens diet and egg storage time

\begin{tabular}{|c|c|c|c|c|c|}
\hline \multirow{2}{*}{$\begin{array}{l}\text { Storage time } \\
\text { (week) }\end{array}$} & \multirow[t]{2}{*}{ Group } & \multicolumn{4}{|c|}{ Colour parameters } \\
\hline & & $L^{*}$ & $a^{*}$ & $\boldsymbol{b}^{*}$ & $\Delta E^{*}$ \\
\hline \multirow[t]{5}{*}{1} & $C$ & $57.97 \pm 0.51^{\mathrm{aA}}$ & $-5.33 \pm 0.38^{a}$ & $13.70 \pm 0.57^{\mathrm{AA}}$ & 0.00 \\
\hline & $\mathrm{E} 1$ & $56.89 \pm 0.05^{\mathrm{bA}}$ & $-4.72 \pm 0.98^{b}$ & $10.08 \pm 1.03^{\mathrm{aA}}$ & 3.70 \\
\hline & E2 & $68.87 \pm 0.46^{\mathrm{cA}}$ & $-4.59 \pm 0.71^{b}$ & $9.39 \pm 0.52^{\mathrm{bA}}$ & 12.22 \\
\hline & E3 & $69.47 \pm 0.74^{\mathrm{dA}}$ & $-4.79 \pm 0.51^{b}$ & $9.79 \pm 0.09^{\mathrm{aA}}$ & 12.64 \\
\hline & E4 & $56.66 \pm 0.12^{\mathrm{eA}}$ & $-4.37 \pm 0.64^{c}$ & $8.80 \pm 0.04^{\mathrm{cA}}$ & 5.06 \\
\hline \multirow[t]{5}{*}{2} & C & $56.90 \pm 0.31^{\mathrm{aA}}$ & $-4.28 \pm 0.22^{a}$ & $9.08 \pm 0.78^{\mathrm{aA}}$ & 0.00 \\
\hline & E1 & $57.89 \pm 0.47^{\mathrm{bA}}$ & $-5.29 \pm 0.32^{b}$ & $13.18 \pm 1.50^{\mathrm{aA}}$ & 4.34 \\
\hline & E2 & $57.34 \pm 0.31^{\mathrm{cA}}$ & $-4.76 \pm 0.34^{c}$ & $10.99 \pm 1.56^{\mathrm{bA}}$ & 2.28 \\
\hline & E3 & $57.45 \pm 0.29^{d A}$ & $-4.93 \pm 0.29^{c}$ & $12.10 \pm 1.28^{\mathrm{aA}}$ & 1.40 \\
\hline & E4 & $57.35 \pm 0.71^{\mathrm{eA}}$ & $-4.88 \pm 0.26^{c}$ & $11.63 \pm 1.05^{\mathrm{cA}}$ & 0.89 \\
\hline \multirow[t]{5}{*}{3} & $\mathrm{C}$ & $56.82 \pm 0.18^{\mathrm{aB}}$ & $-4.39 \pm 0.08^{a}$ & $9.68 \pm 0.42^{\mathrm{aB}}$ & 0.00 \\
\hline & E1 & $57.26 \pm 0.32^{\mathrm{bB}}$ & $-4.70 \pm 0.52^{b}$ & $12.04 \pm 0.09^{\mathrm{aB}}$ & 1.27 \\
\hline & E2 & $57.12 \pm 0.08^{\mathrm{cB}}$ & $-4.39 \pm 0.12^{a}$ & $9.67 \pm 0.73^{\mathrm{bB}}$ & 1.24 \\
\hline & E3 & $56.88 \pm 0.36^{\mathrm{dB}}$ & $-4.51 \pm 0.21^{a}$ & $10.23 \pm 0.72^{\mathrm{aB}}$ & 0.57 \\
\hline & E4 & $56.82 \pm 0.44^{\mathrm{eB}}$ & $-4.58 \pm 0.33^{a}$ & $10.40 \pm 1.31^{\mathrm{CB}}$ & 0.20 \\
\hline \multirow[t]{5}{*}{4} & C & $56.80 \pm 0.78^{\mathrm{aB}}$ & $-5.25 \pm 0.38^{a}$ & $12.75 \pm 0.70^{\mathrm{aB}}$ & 0.00 \\
\hline & E1 & $56.92 \pm 0.32^{\mathrm{bc}}$ & $-4.58 \pm 0.44^{b}$ & $10.62 \pm 1.92^{\mathrm{aB}}$ & 2.24 \\
\hline & E2 & $57.04 \pm 0.05^{\mathrm{cC}}$ & $-4.70 \pm 0.25^{b}$ & $10.99 \pm 1.14^{\mathrm{bB}}$ & 0.45 \\
\hline & E3 & $57.20 \pm 0.17^{\mathrm{dc}}$ & $-4.95 \pm 0.25^{b}$ & $12.29 \pm 1.18^{\mathrm{aB}}$ & 1.38 \\
\hline & E4 & $57.45 \pm 0.36^{\mathrm{eC}}$ & $-4.85 \pm 0.30^{b}$ & $11.74 \pm 1.13^{\mathrm{cB}}$ & 0.85 \\
\hline \multicolumn{6}{|c|}{ Two-way ANOVA $p$ value } \\
\hline \multicolumn{2}{|c|}{ Type of phyto-additive } & $<0.001$ & NS & $<0.05$ & \\
\hline \multicolumn{2}{|c|}{ Storage time } & $<0.001$ & NS & $<0.01$ & \\
\hline \multicolumn{2}{|c|}{$\begin{array}{l}\text { Type of phyto-additivexStorage } \\
\text { time }\end{array}$} & $<0.001$ & $<0.05$ & $<0.001$ & \\
\hline
\end{tabular}

${ }^{*} \mathrm{C}$, control group which consumed a complete feeding mixture without the addition of phyto-additives; E1, feeding mixture with bilberry leaves; E2, feeding mixture with walnut leaves; E3, feeding mixture with sea-buckthorn pomace; E4, feeding mixture with mix of bilberry leaves, sea-buckthorn pomace and walnut leaves, in equal proportions.Different lowercase letters in vertical indicate difference between diets $(p \leq 0.05)$; Different uppercase letters in horizontal shown difference between time of storage $(p \leq 0.05)$. Data are showed as mean \pm standard deviation

of $L^{*}$ and $b^{*}$ was obtained in E2 group when walnut leaves are used to supplement the feed for laying hens. With the addition of sea-buckthorn pomace in hens feed, there was a significant decrease of $a^{*}$ and an increase of $b^{*}$, meaning lower redness and higher yellowness of egg yolk. Other authors reported a markedly increased of $a^{*}$ and $b^{*}$ parameters with the amount of added seabuckthorn pomace in hens feed (Dvořák et al., 2017). Also, a high yellowness was found in E4 group, whose diet was enhanced with a mix of bilberry leaves, sea-buckthorn pomace and walnut leaves, in equal proportions. An increase of luminosity was obtained in E4 group when a mixture of bilberry leaves, sea-buckthorn pomace and walnut leaves, in equal proportions was added in hens diet. Mansoori et al. (2008) reported that the supplementation of a hens diet with dried tomato pulp led to a more intense egg yolk colour, while Chong et al. (2008) revealed the significantly lighter colour of the yolk when extracted palm kernel pomace was added in the hens diet. The $\Delta E^{*}$ showed very small differences compare to the control. The ANOVA test of differences in yolk colour during storage showed a significant difference $(p<0.05)$ among weeks of storage. It was found that the colour changes on the last week of storage were higher for the control group compared to the experimental groups. The results of twoway ANOVA showed that the interaction between type of phyto-additive and storage time have not a significant effect $(p>0.05)$ on colour of egg yolks.

The addition of novel phyto-additives in the hens feed changes the values of egg yolk colour parameters $L^{*}, a^{*}$ and $b^{*}$ (Table 2). An increase of $L^{*}$ value was obtained for E1 and E4 groups, compared to control group, while it decreases for E2 group. The decrease of the intensity of egg yolk from E2 group can be due to the walnut leaves from hens diet, yolk pigmentation being mainly due to dietary factors (Minelli et al., 2007). The addition of bilberry leaves leads to an increase of colourity intensity which is related to the $L^{*}$ parameter. The parameter $\Delta E^{*}$ remarkable increases, depending on the phyto-additive type added to the hens feed. The composition of feeding is reflected in the resultant variation of colour parameters. 
Panaite, et al.

Table 2:Colour parameters of the liquid egg yolk in relation to the phyto-additives added in hens diet and egg storage time

\begin{tabular}{|c|c|c|c|c|c|}
\hline \multirow{2}{*}{$\begin{array}{l}\text { Storage time } \\
\text { (week) }\end{array}$} & \multirow[t]{2}{*}{ Group } & \multicolumn{4}{|c|}{ Colour parameters } \\
\hline & & $L^{*}$ & $a^{*}$ & $b^{*}$ & $\Delta E^{\star}$ \\
\hline \multirow[t]{5}{*}{1} & C & $59.38 \pm 0.92^{\mathrm{a}}$ & $-4.98 \pm 0.86^{a A}$ & $54.05 \pm 0.73^{\mathrm{aA}}$ & 0.00 \\
\hline & $\mathrm{E} 1$ & $59.81 \pm 0.72$ & $-5.40 \pm 0.34^{A}$ & $54.16 \pm 0.26^{A}$ & 0.61 \\
\hline & E2 & $58.10 \pm 2.68^{b}$ & $-5.44 \pm 0.59^{\mathrm{bA}}$ & $49.87 \pm 0.65^{A}$ & 5.02 \\
\hline & E3 & $59.34 \pm 0.75$ & $-2.92 \pm 0.69^{\mathrm{cA}}$ & $55.33 \pm 0.99^{\mathrm{bA}}$ & 2.46 \\
\hline & E4 & $59.69 \pm 0.91$ & $-4.75 \pm 0.78^{\mathrm{dA}}$ & $55.26 \pm 0.85^{\mathrm{cA}}$ & 3.34 \\
\hline \multirow[t]{5}{*}{2} & C & $59.72 \pm 0.65^{a}$ & $-6.21 \pm 0.82^{\mathrm{aB}}$ & $50.52 \pm 1.53^{\mathrm{aB}}$ & 0.00 \\
\hline & $\mathrm{E} 1$ & $57.92 \pm 0.22$ & $-6.38 \pm 0.51^{B}$ & $51.14 \pm 1.42^{B}$ & 0.62 \\
\hline & E2 & $57.55 \pm 0.91^{b}$ & $-5.74 \pm 0.24^{\mathrm{bB}}$ & $52.63 \pm 0.59^{\mathrm{B}}$ & 2.11 \\
\hline & E3 & $57.21 \pm 0.74$ & $-3.71 \pm 0.31^{\mathrm{CB}}$ & $54.74 \pm 0.78^{\mathrm{bB}}$ & 4.22 \\
\hline & E4 & $58.56 \pm 0.74$ & $-5.10 \pm 0.06^{\mathrm{dB}}$ & $51.60 \pm 1.11^{\mathrm{CB}}$ & 1.08 \\
\hline \multirow[t]{5}{*}{3} & C & $58.68 \pm 0.65^{a}$ & $-6.78 \pm 0.22^{\mathrm{ac}}$ & $49.16 \pm 0.51^{\mathrm{aC}}$ & 0.00 \\
\hline & E1 & $59.12 \pm 1.53$ & $-6.20 \pm 0.14^{c}$ & $50.50 \pm 0.98^{c}$ & 1.34 \\
\hline & E2 & $57.92 \pm 1.12^{b}$ & $-5.77 \pm 1.02^{\mathrm{bC}}$ & $51.25 \pm 0.38^{c}$ & 2.09 \\
\hline & E3 & $57.89 \pm 1.01$ & $-3.77 \pm 0.53^{\mathrm{cc}}$ & $55.15 \pm 0.52^{\mathrm{bC}}$ & 5.99 \\
\hline & E4 & $59.45 \pm 0.23$ & $-4.66 \pm 0.07^{d C}$ & $54.96 \pm 0.54^{\mathrm{cc}}$ & 5.80 \\
\hline \multirow[t]{5}{*}{4} & $\mathrm{C}$ & $56.64 \pm 0.99^{a}$ & $-5.95 \pm 0.17^{\mathrm{aD}}$ & $51.45 \pm 0.96^{\mathrm{aD}}$ & 0.00 \\
\hline & $\mathrm{E} 1$ & $57.89 \pm 0.95$ & $-5.98 \pm 0.22^{D}$ & $51.92 \pm 0.70^{\mathrm{D}}$ & 0.47 \\
\hline & E2 & $57.01 \pm 0.50^{\mathrm{b}}$ & $-4.98 \pm 0.63^{\mathrm{bD}}$ & $52.15 \pm 0.74^{\mathrm{D}}$ & 0.70 \\
\hline & E3 & $57.60 \pm 0.83$ & $-4.35 \pm 0.62^{\mathrm{cD}}$ & $53.27 \pm 0.48^{\mathrm{bD}}$ & 1.82 \\
\hline & E4 & $57.28 \pm 0.36$ & $-5.09 \pm 0.72^{\mathrm{dD}}$ & $52.81 \pm 0.46^{\mathrm{cD}}$ & 1.36 \\
\hline \multicolumn{6}{|c|}{ Two-way ANOVA $p$ value } \\
\hline \multicolumn{2}{|c|}{ Type of phyto-additive } & $<0.001$ & $<0.001$ & $<0.001$ & \\
\hline \multicolumn{2}{|c|}{ Storage time } & $<0.001$ & $<0.01$ & $<0.001$ & \\
\hline \multicolumn{2}{|c|}{ Type of phyto-additivexStorage time } & $<0.01$ & NS & $<0.001$ & \\
\hline
\end{tabular}

${ }^{*} \mathrm{C}$, control group which consumed a complete feeding mixture without the addition of phyto-additives; E1, feeding mixture with bilberry leaves; E2, feeding mixture with walnut leaves; E3, feeding mixture with sea-buckthorn pomace; E4, feeding mixture with mix of bilberry leaves, sea-buckthorn pomace and walnut leaves, in equal proportions. Different lowercase letters in vertical indicate difference between diets $(p \leq 0.05)$; Different uppercase letters in horizontal shown difference between time of storage $(p \leq 0.05)$. Data are showed as mean \pm standard deviation

\section{Effect of hens diet and egg storage on $\mathrm{pH}$-value of liquid egg components}

The results on the effect of feed hens and egg storage time on $\mathrm{pH}$ values of liquid egg components measured at each week for a period of 4 weeks are showed in Table 3. Egg albumen $\mathrm{pH}$ was dependent on the storage and showed an increase progressively by increasing storage time during the first 3 weeks of storage. After this period, $\mathrm{pH}$ value exhibits a decrease, but the values were always superior to $\mathrm{pH}$ 9. The results are in disagreement with those obtained by Walsh et al. (1995) which reported that storage time have not an influence on the albumen $\mathrm{pH}$. Studies made by other researchers have reported an increase of $\mathrm{pH}$ value by extending the storage time duration (Kumbar et al., 2015). The increase of $\mathrm{pH}$ is affected by the ovomucina-lysozyma complex and leds to the liquefaction of albumen. Egg albumen was pseudoplastic at $\mathrm{pH}$ values 3,4 and from 7 to 10 , but that it behaves as a Newtonian fluid at $\mathrm{pH}$ values 5, 6 and 11 (Gossett et al., 1983).

An increase of $\mathrm{pH}$ with the storage length was obtained in all egg yolk samples. The increase of $\mathrm{pH}$ observed in yolk was not as large as in albumen, and it was different as function of phyto-additive type added in hens diet. Overall increases of the yolk $\mathrm{pH}$ were observed at the end of the storage time. This may be related to the deterioration of the yolk quality as a consequence of moisture evaporation and carbon dioxide loss. These changes lead to an increase of the $\mathrm{pH}$ and concomitant structural change in the yolk protein (Chung and Lee, 2014).

A decrease of alkalinity in whole liquid egg even after 3 weeks of storage time was observed in control group. In contrast, in E1, E2, E3 and E4 groups a slightly increase of alkalinity was obtained. The trend was not uniform during all storage periods. The results obtained indicated that $\mathrm{pH}$ parameter can be a useful tool for describing the changes in egg components quality diet over time during storage and in function of phyto-additve added in hens.

The increase of $\mathrm{pH}$ observed in all egg components was not as large in E1, E2, E3 and E4 groups compared to control. The feeding mixture with phyto-additives didn't affect significantly $(p>0.05)$ egg yolk $\mathrm{pH}$ value, except 
Panaite, et al.

Table 3: Egg products $\mathrm{pH}$ in relation to the dietary supplementation with phyto-additive and storage time

\begin{tabular}{|c|c|c|c|c|c|}
\hline \multirow[t]{2}{*}{ Product } & \multirow[t]{2}{*}{ Group* } & \multicolumn{4}{|c|}{$\mathrm{pH}$ value during storage time } \\
\hline & & 1 week & 2 week & 3 week & 4 week \\
\hline \multirow[t]{5}{*}{ Liquid egg albumen } & C & $9.11 \pm 0.01^{\mathrm{aA}}$ & $9.12 \pm 0.04^{\mathrm{aB}}$ & $9.25 \pm 0.08^{\mathrm{aC}}$ & $9.20 \pm 0.04^{\mathrm{aB}}$ \\
\hline & E1 & $9.02 \pm 0.04^{\mathrm{aA}}$ & $9.21 \pm 0.04^{\mathrm{aB}}$ & $9.25 \pm 0.04^{\mathrm{ac}}$ & $9.18 \pm 0.03^{\mathrm{aB}}$ \\
\hline & E2 & $9.02 \pm 0.05^{\mathrm{bA}}$ & $9.14 \pm 0.08^{\mathrm{bB}}$ & $9.18 \pm 0.05^{\mathrm{bC}}$ & $9.08 \pm 0.05^{\mathrm{bB}}$ \\
\hline & E3 & $9.02 \pm 0.05^{\mathrm{cA}}$ & $9.17 \pm 0.06^{\mathrm{cB}}$ & $9.20 \pm 0.03^{\mathrm{cC}}$ & $9.12 \pm 0.06^{\mathrm{CB}}$ \\
\hline & E4 & $9.03 \pm 0.01^{\mathrm{aA}}$ & $9.12 \pm 0.10^{\mathrm{aB}}$ & $9.28 \pm 0.05^{\mathrm{ac}}$ & $9.17 \pm 0.02^{\mathrm{aB}}$ \\
\hline \multirow[t]{5}{*}{ Liquid egg yolk } & C & $6.04 \pm 0.09^{\mathrm{aA}}$ & $6.31 \pm 0.02^{\mathrm{aA}}$ & $6.21 \pm 0.09^{\mathrm{aA}}$ & $6.35 \pm 0.09^{\mathrm{aA}}$ \\
\hline & $\mathrm{E} 1$ & $6.02 \pm 0.09^{\mathrm{aA}}$ & $6.24 \pm 0.09^{\mathrm{aA}}$ & $6.25 \pm 0.07^{\mathrm{aA}}$ & $6.26 \pm 0.03^{\mathrm{aA}}$ \\
\hline & E2 & $6.06 \pm 0.08^{\mathrm{aA}}$ & $6.08 \pm 0.09^{\mathrm{aA}}$ & $6.17 \pm 0.06^{\mathrm{aA}}$ & $6.23 \pm 0.02^{\mathrm{aA}}$ \\
\hline & E3 & $6.04 \pm 0.03^{\mathrm{bA}}$ & $6.15 \pm 0.02^{\mathrm{A}}$ & $6.19 \pm 0.08^{\mathrm{bA}}$ & $6.20 \pm 0.09^{\mathrm{bA}}$ \\
\hline & E4 & $6.04 \pm 0.05^{\mathrm{aA}}$ & $6.03 \pm 0.04^{\mathrm{aA}}$ & $6.23 \pm 0.09^{\mathrm{aA}}$ & $6.26 \pm 0.09^{\mathrm{aA}}$ \\
\hline \multirow[t]{5}{*}{ Whole liquid egg } & C & $7.52 \pm 0.08^{\mathrm{aA}}$ & $7.41 \pm 0.08^{\mathrm{aA}}$ & $7.39 \pm 0.04^{\mathrm{aB}}$ & $7.45 \pm 0.02^{\mathrm{aA}}$ \\
\hline & $\mathrm{E} 1$ & $7.38 \pm 0.09^{\mathrm{aA}}$ & $7.46 \pm 0.09^{\mathrm{aA}}$ & $7.39 \pm 0.08^{\mathrm{aA}}$ & $7.33 \pm 0.09^{\mathrm{aA}}$ \\
\hline & E2 & $7.36 \pm 0.02^{\mathrm{aA}}$ & $7.37 \pm 0.05^{\mathrm{aA}}$ & $7.27 \pm 0.05^{\mathrm{aA}}$ & $7.47 \pm 0.06^{\mathrm{aA}}$ \\
\hline & E3 & $7.26 \pm 0.04^{\mathrm{bA}}$ & $7.45 \pm 0.07^{\mathrm{bA}}$ & $7.51 \pm 0.09^{\mathrm{bA}}$ & $7.27 \pm 0.06^{\mathrm{bA}}$ \\
\hline & E4 & $7.21 \pm 0.02^{\mathrm{bA}}$ & $7.27 \pm 0.09^{\mathrm{bA}}$ & $7.47 \pm 0.07^{\mathrm{bA}}$ & $7.38 \pm 0.07^{\mathrm{bA}}$ \\
\hline
\end{tabular}

${ }^{*} \mathrm{C}$, control group which consumed a complete feeding mixture without the addition of phyto-additives; E1, feeding mixture with bilberry leaves; E2, feeding mixture with walnut leaves; E3, feeding mixture with sea-buckthorn pomace; E4, feeding mixture with mix of bilberry leaves, sea-buckthorn pomace and walnut leaves, in equal proportions. Different lowercase letters in vertical indicate difference between diets $(p \leq 0.05)$; Different uppercase letters in horizontal shown difference between time of storage $(p \leq 0.05)$. Data are showed as mean \pm standard deviation

E3 group where the hens diet was supplemented with sea-buckthorn pomace. Regarding the whole liquid yolk $\mathrm{pH}$, significant value $(p<0.05)$ was obtained between $\mathrm{C}$ and $\mathrm{E} 3$ and, $\mathrm{E} 4$ respectively. These results can be related to the synergistic effect of phytochemical compounds from diet. An increase of $\mathrm{pH}$ value was obtained in some groups treatment which can be explained by the loss of $\mathrm{CO}_{2}$ from the egg. During storage, the albumen becomes thinner and loses $\mathrm{CO}_{2}$, which allows the electrostatic complex between the lysozyme and ovomucin to rupture, which helps increase the $\mathrm{pH}$ of eggs (Scott and Silversides, 2000).

At the same time no significant changes $(\phi>0.05)$ were obtained for the whole liquid egg $\mathrm{pH}$ in function of treatment groups of E1 and E2 compared to control. The interaction effect between hen's diet and storage time were significantly $(p<0.05)$ with respect to whole liquid egg $\mathrm{pH}$ (Table 3).

All liquid egg components, albumen, yolk and whole egg $\mathrm{pH}$ were influenced by the type of phyto-aditive added in hen's diet and egg storage time. The results obtained highlighted that the $\mathrm{pH}$ values were only slightly dependent on the storage period. Similar results have been obtained by the Tilki and Inal (2004).

\section{Effect of hens diet and egg storage on the viscosity of liquid egg components}

The apparent viscosity of liquid egg components were measured at room temperature $\left(20 \pm 1^{\circ} \mathrm{C}\right)$ as a function of strain rate with increasing shear rate. The shear rate varied from 0 to $100 \mathrm{~s}^{-1}$ and de duration of the experiment was set to $60 \mathrm{~s}$.
As it is visible in Fig. 1, the value of albumen viscosity changes with eggs storage time. The dependence shows that albumen exhibit shear-thinning behaviour, the apparent viscosity decreasing with shear rate. Lower viscosity did not change foam density and stability. The E2 group showed a higher viscosity compared to E1, E3 and E4 after 1 week of storage. This behaviour can be related to the constituents from walnut leaves from feeding mixture. The ovomucina-lysozyna complex which is stabilized by electrostatic connections can be responsible for higher viscosity of the albumen in eggs after 1 week. A decrease of albumen viscosity was obtained after 3 week in $C$ group compared to E1, E2, E3 and E4 groups. This decrease can be explained by the liquefaction of albumen due to the increase of $\mathrm{pH}$. Therefore, the diet supplemented with the phyto-additives can improve the albumen viscosity of eggs. An increase of albumen viscosity during storage was obtained for E2 after 3 and 4 weeks; at lower shear rates there is a tendency toward an increase of albumen viscosity.

The viscosity values obtained for egg yolk showed differences between samples due to the varied hens diet (Fig. 1). Compared to the control, a high value for viscosity after 1 week was obtained in egg from hens witch has a diet supplemented with phyto-addditives (Fig. 1). The yolk viscosity values decrease with storage time increase. The decrease of yolk viscosity with storage time can be related to the decreasing number of interactions in yolk structure occurring during storage.

The decrease of gel presence with storage was observed by Sakanaka et al. (2000) which found that the complex modulus 

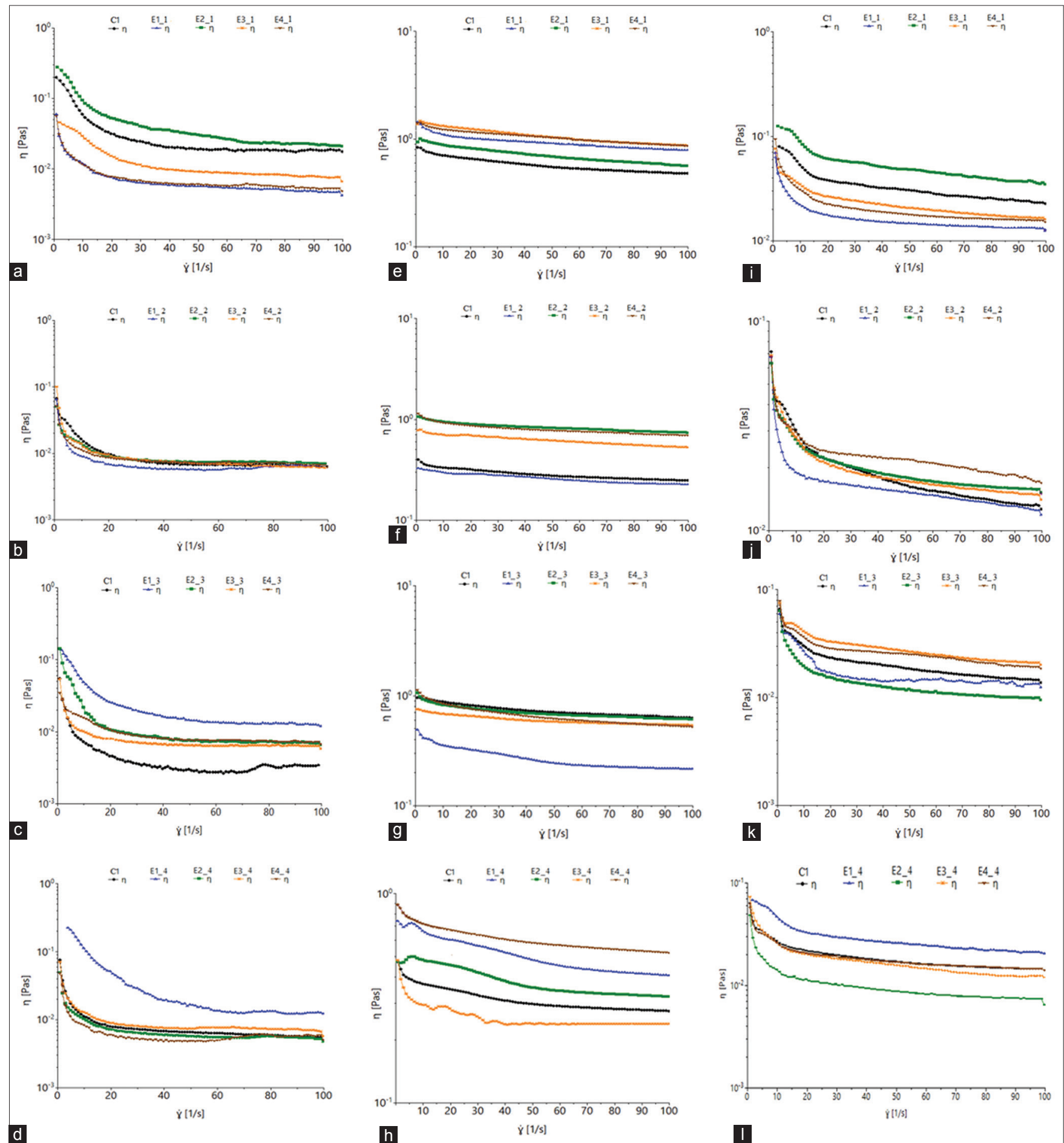

Fig 1. Variation of egg albumen (a-d), egg yolk (e-h), and whole egg (i-l) viscosity during egg storage time: (a, e, i) 1 week; (b, f, j) 2 week; (c, g, k) 3week; (d, h, I) 4 week as a response of a hens diet supplemented with different phyto-additives.

of the yolk decreases in time. The component rearrangement which was in progress throughout the storage period and fewer contacts which are present can be an explanation for this behavior (Severa et al. 2010). It is obvious that viscosity values decreases with shear rate increase, yolk exhibiting shear-thiningbehaviour. This behaviour was expected in yolk because its texture is influenced by weak physical bonds and hydrophobic interactions (Atílgan and Unluturk, 2008). The decrease of the yolk viscosity with shear rate can to be a response of destruction of the interactions between the main components of the egg yolk, triacylglycerols, phospholipids, proteins and carbohydrates.

The effect of hens diet supplemented with novel phyto-additives on the flow behaviour of the whole liquid 
egg during storage time is showed in Figure 1. The apparent viscosity value varies in function of type of phyto-additives added in the hens diet, and there is the possibility to identify eggs from hen feeding with phyto-additives by determining whole egg viscosity. The viscosity decreases with storage time increase, a high decrease was obtained in eggs from E2 group after 4 weeks compared to the 1 week. This behaviour can lead to an increased emulsifying ability and whipping performance of the whole liquid egg.

The evaluation of the rheological behaviour of liquid egg components highlighted the non-Newtonian rhologicalbehaviour. Ostwald-De Waele rheological flow model (Eq. 3) based on shear stress was applied (Rao, 2013):

$$
\tau=\mathrm{K} \cdot \gamma^{\mathrm{n}}
$$

Where $\tau$ is the shear stress $(\mathrm{Pa}), \gamma$ is the shear strain rate $\left(\mathrm{s}^{-1}\right), K$ is the consistency index $\left(\mathrm{Pa}-\mathrm{s}^{\mathrm{n}}\right)$ and $n$ is the flow behavior index.

The application of Ostwald-de Waele model, also known as power-law, was selected because it presents a technical and practical advantage in the design of piping and pumping systems for food processing, like modeling of continuous pasteurization in pipes (Kumbar et al., 2015a), compared to other rheological models.

The addition of phyto-additives to the feed and storage time of eggs influence the consistency of liquid egg component in various ways. The parameters of the tested model, Eq. (3) for all liquid egg components evaluated are showed in Table 4.

As it can be seen, the coefficient of determination $\left(R^{2}\right)$ revealed goodness of the model fit to the experimental data due to his higher value. The flow behaviour index, $n$ of egg albumen suggested a pseudoplasticbehaviour for shear rates from 0 to $100 \mathrm{~s}^{-1}$ and did not undergo great variations with added phyto-additives in hens diet. It has tended to increase with the egg storage time. A comparison of $n$ values with those reported in other studies showed that the flow behaviour index values is close to those obtained by Lucisano et al. (1996) and Kumbar et al. (2015). The consistency index, $K$ decreased with the storage time due to the viscosity decrease. This change can be attributed to water loss by evaporation

Table 4: Liquid egg products parameters of the Ostwald-de Waele model

\begin{tabular}{|c|c|c|c|c|c|c|c|c|c|c|}
\hline \multirow[t]{2}{*}{ Group } & \multirow[t]{2}{*}{ Storage duration (Weeks) } & \multicolumn{3}{|c|}{ Egg albumen } & \multicolumn{3}{|c|}{ Egg yolk } & \multicolumn{3}{|c|}{ Whole liquid egg } \\
\hline & & $\begin{array}{c}\mathrm{K} \\
\left(\mathrm{Pa} \cdot \mathrm{s}^{-\mathrm{n}}\right) \\
\end{array}$ & $\mathrm{n}$ & $R^{2}$ & $\begin{array}{c}K \\
\left(\mathrm{~Pa} \cdot \mathrm{s}^{-n}\right) \\
\end{array}$ & $n$ & $R^{2}$ & $\begin{array}{c}\mathrm{K} \\
\left(\mathrm{Pa} \cdot \mathrm{s}^{-n}\right)\end{array}$ & $n$ & $R^{2}$ \\
\hline \multirow[t]{4}{*}{ C } & 1 & 0.0614 & 0.7061 & 0.9213 & 1.3980 & 0.7620 & 0.9994 & 0.0989 & 0.6549 & 0.9987 \\
\hline & 2 & 0.0153 & 0.7168 & 0.9824 & 0.5188 & 0.8317 & 0.9997 & 0.0647 & 0.6629 & 0.9996 \\
\hline & 3 & 0.0201 & 0.7450 & 0.9821 & 0.5939 & 0.8540 & 0.9998 & 0.0596 & 0.6603 & 0.9990 \\
\hline & 4 & 0.0189 & 0.7816 & 0.9949 & 0.9131 & 0.8437 & 0.9995 & 0.0384 & 0.7161 & 0.9995 \\
\hline \multirow[t]{4}{*}{ E1 } & 1 & 0.0227 & 0.7260 & 0.9653 & 2.6715 & 0.7855 & 0.9994 & 0.0450 & 0.6716 & 0.9993 \\
\hline & 2 & 0.0161 & 0.7657 & 0.9947 & 0.5359 & 0.8368 & 0.9998 & 0.0531 & 0.7390 & 0.9983 \\
\hline & 3 & 0.0591 & 0.7486 & 0.9727 & 1.0460 & 0.8591 & 0.9996 & 0.0608 & 0.6625 & 0.9974 \\
\hline & 4 & 0.0287 & 0.7864 & 0.9921 & 1.3070 & 0.8446 & 0.9997 & 0.0521 & 0.7168 & 0.9995 \\
\hline \multirow[t]{4}{*}{ E2 } & 1 & 0.0355 & 0.7381 & 0.9824 & 1.8270 & 0.7899 & 0.9995 & 0.1549 & 0.6875 & 0.9990 \\
\hline & 2 & 0.0344 & 0.7690 & 0.9866 & 1.3270 & 0.8393 & 0.9998 & 0.0772 & 0.7528 & 0.9973 \\
\hline & 3 & 0.0269 & 0.7576 & 0.9801 & 0.9954 & 0.8652 & 0.9998 & 0.0320 & 0.6794 & 0.9996 \\
\hline & 4 & 0.0141 & 0.8045 & 0.9963 & 0.8113 & 0.8595 & 0.9997 & 0.0338 & 0.7318 & 0.9993 \\
\hline \multirow[t]{4}{*}{ E3 } & 1 & 0.0349 & 0.7417 & 0.9888 & 2.4895 & 0.7918 & 0.9995 & 0.0393 & 0.8483 & 0.9997 \\
\hline & 2 & 0.0166 & 0.7725 & 0.9964 & 0.6473 & 0.8505 & 0.9998 & 0.0488 & 0.7554 & 0.9992 \\
\hline & 3 & 0.0167 & 0.8065 & 0.9947 & 0.7523 & 0.8899 & 0.9993 & 0.0589 & 0.6919 & 0.9994 \\
\hline & 4 & 0.0147 & 0.8548 & 0.9954 & 1.1823 & 0.8754 & 0.9997 & 0.0533 & 0.7406 & 0.9993 \\
\hline \multirow[t]{4}{*}{ E4 } & 1 & 0.0358 & 0.7509 & 0.9922 & 2.5310 & 0.8210 & 0.9994 & 0.0490 & 0.7550 & 0.9976 \\
\hline & 2 & 0.0320 & 0.7825 & 0.9902 & 0.6959 & 0.8664 & 0.9999 & 0.0732 & 0.7348 & 0.9976 \\
\hline & 3 & 0.0152 & 0.8144 & 0.9883 & 1.5140 & 0.8964 & 0.9999 & 0.0721 & 0.6958 & 0.9976 \\
\hline & 4 & 0.0061 & 0.9003 & 0.9939 & 0.9738 & 0.8808 & 0.9999 & 0.0462 & 0.7490 & 0.9976 \\
\hline
\end{tabular}

${ }^{*} \mathrm{C}$, control group which consumed a complete feeding mixture without the addition of phyto-additives; E1, feeding mixture with bilberry leaves; E2, feeding mixture with walnut leaves; E3, feeding mixture with sea-buckthorn pomace; E4, feeding mixture with mix of bilberry leaves, sea-buckthorn pomace and walnut leaves, in equal proportions. $R^{2}$ is the coefficient of determination 
through the pores in the shell and the escape of $\mathrm{CO}_{2}$ from egg albumen. The effect of these changes can be observed by a decline of egg albumen quality during storage time.

The liquid egg yolk shows more remarkable non-Newtonian behaviour, the values of the flow behaviour index $n$ being higher than those obtained for the albumen (Table 4). An increase of $n$ value was obtained for E1, E2, E3 and E4 groups compared to the control. This behaviour can be related to the novel phyto-additives added in hens diet, a higher increase being found in E3 and E4 groups. The increase could be attributed the presence of phytochemicals compounds from sea-buckthorn pomace and from the mix of bilberry leaves, sea-buckthorn pomace and walnut leaves which were included in the feed. In according to another study (Abbasnezhad et al., 2015) the non-Newtonian behavior of egg yolk can be due to the phosphate and lipoproteins or other complex molecules. The high content in lipid in the food system may favor the formation of some protein-lipid complexes which will affect the viscosity (Codina and Mironeasa, 2016; Mironeasa et al., 2012). The egg yolk proteins being high molecular weight soluble polymers can greatly increase the viscosity even at very low concentrations. During storage, the viscosity increases in the experimental groups as a function of phyto-additives added in hens diet.

The whole liquid egg has a similar non-Newtonian behavior with egg albumen and yolk (Table 4), Ostwald-de Waele rheological model being suitable. As it was expected, whole egg behaves as a pseudoplastic, fact suggested by the the flow behaviour and consistency coefficient values. During egg storage, an increase of flow behaviour index was also obvious. This behaviour can be related to the integrity of the ovomucin-lysozyme complex, and particularly on the $\beta$-fraction of ovomucin (Kato et al., 1970).

The results of these experiments proved that under controlled feeding conditions, certain changes in liquid egg components, in terms of albumen, yolk and whole egg can be observed. The evaluation of the rheological properties shows the changes of liquid egg components with storage time. Remarkable changes can be noticed on the flow behaviour index and the consistency coefficient in function of the phyto-additive type added in hens diet.

\section{CONCLUSIONS}

The properties of liquid egg components as influenced by some phyto-additives incorporated in hens diet and measured during storage can have essential applications in egg industry. According to the results obtained, the best characteristics were recorded for eggs provided by the hens whose diet was supplemented with walnut leaves. The liquid egg components differed significantly in traits, namely colour,pH and rheological properties. The viscosity of the liquid egg components decreases with the time of egg storage. The rheological test allows determining the differences between eggs which provide from a varied diet of hens with phyto-additives according to their values of flow behavior and consistency indexes. The consistency index highlights better the differences between hens diets during storage time and could be used to determine the egg freshness. The properties of liquid egg components determined make possible to improve the diet of hens in order to obtain desired quality for eggs. The monitoring of the rheological behaviour of liquid hens egg components during storage time could be of interest in the design of egg conservation conditions and consequently its quality control. The results obtained could be useful in the design of piping and pumping systems for food processing industry.

\section{ACKNOWLEDGEMENTS}

This work was supported by a grant of the Romanian National of Research and Innovation, CCCDI - UEFISCDI, project number PN-III-P1-1.2-PCCDI-2017-0473, within PNCDI III.

\section{Authors' contributions}

Tatiana DumitraPanaite, Silvia Mironeasa, MădălinaIuga, and PetruAlexandruVlaicu contributed equally to th study design, collection of data, development of the sampling, analyses, interpretation of results, and preparation of the paper. All authors read and approved the final manuscript.

\section{REFERENCES}

Abbasnezhad, B., N. Hamdami and D. Khodaei. 2015. Modeling of rheological characteristics of liquid egg white and yolk at different pasteurization temperatures. Food Measure Meas. 9: 359-368.

Arpášová, H., M.Kačániová, P. Haščík and V. Šidlová. 2012. Effect of selected feed additives on internal quality parameters of table eggs. Potravinarstvo Slovak J. Food Sci. 6: 52-61.

Atílgan, M. R. and S. Unluturk. 2008. Rheological properties of liquid egg products (LEPS). Int. J. Food Prop. 11: 296-309.

Beveridge, T. and S. Nakai. 1975. Effects of sulphydryls blocking on the thinning of egg white. J. Food Sci. 40: 864-868.

Burley, R. W. and D. V. Vadehra. 1989. The albumen: Chemistry. In: The Avian Egg. Chemistry and Biology, . Wiley: , New York.

Cabral, R. A. F., V. R. N. Telis, K. J. Park and J. Telis-Romero. 2011. Friction losses in valves and fittings for liquid food products. Food Bioprod. Process Proc. 89: 375-382.

Chong, C. H., I. Zulkifli and R. Blair. 2008. Effects of dietary inclusion of palm kernel cake and palm oil, and enzyme supplementation on performance of laying hens. Asian-Aust. J. Anim. Sci. 


\section{1: 1053-1058}

Chung, S. H. and K. W. Lee. 2014. Effect of hen age, storage duration and temperature on egg quality in laying hens. Int. J. Poult. Sci. 13: 634-636.

Codină, G. G. and S. Mironeasa. 2016. Use of response surface methodology to investigate the effects of brown and golden flaxseed on wheat flour dough microstructure and rheological properties. J. Food Sci. Tech. 53: 4149-4158.

Dvořák, P., P. Suchý, E. Straková and J. Doležalová. 2017. The effect of a diet supplemented with sea-buckthorn pomace on the colour and viscosity of the egg yolk. Acta Vet. Brno. 86: 303-308.

Dvořák, P., P. Suchý, E. Straková and V. Kopriva. 2012. Possibilities of enhancing the colour of egg yolk. J. Sci. Food Agric. 92: 853-856.

Gossett, P. W., S. S. H. Rizvi and R. C. Baker. 1983. Selected rheological properties of $\mathrm{pH}$-adjusted or succinylated egg albumen. J. Food Sci. 48: 1395-1399.

HuopalahtiHuopalahti, R., M. Anton, R. López-Fandiñoand R. Schade. 2007. Bioactive Egg Compounds. Berlin: Springer., Berlin.

leri, F., S. Martini, M. Innocenti and N. Mulinacci. 2013. Phenolic distribution in liquid preparations of Vaccinium myrtillus L. And Vaccinium vitis idaea L. Phytochem. Anal. 24: 467--475.

Jesús, M. N. D., A. B. Zanqui, P. Valderrama, A. Tanamati, S. A. Maruyama, N. E. D. Souza and M. Matsushita 2013. Sensory and physico-chemical characteristics of desserts prepared with egg products processed by freeze and spray drying. Food Science and Tech. 33: 549-554.

Kato, A., R. Nakamura and Y. Sato. 1970. Studies on changes in stored shell eggs. Part V. The difference in the chemical and physicochemical properties of ovomucin (B) between the thick and thin white. Agric. Biol. Chem. 34: 854-859.

Kemps B. J., F. R. Bamelis, K.Mertens, E. M. Decuypere, J. G. De Baerdemaeker and B. De Ketelaere. 2010. The assessment of viscosity measurements on the albumen of consumption eggs as an indicator for freshness. Poult. Sci. 89: 2699-2703.

Kopřiva, V., P. Suchý, E. Straková, M. Žd'árský and P. Dvořák. 2014. Colour and viscosity of egg yolk after addition of beetroot to feed for laying hens. Acta Vet. Brno. 83: 39-44.

Korekar, G., T. Stobdan, H. Singh, O. P. Chaurasia and S. B. Singh. 2011. Phenolic content and antioxidant capacity of various solvent extracts from sea buckthorn (Hippophae rhamnoides L.) fruit pulp, seeds, leaves and stem bark. Acta Aliment. Hung. 40: $449--458$.

Kumbar, V., S. Nedomova, J. Strnkova and J. Buchar. 2015. Effect of egg storage duration on the rheology of liquid egg products. J. Food Eng. 156: 45--54.

Kumbar, V., J. Strnkova, S. Nedomovaand J. Buchar. 2015a. Fluid dynamics of liquid egg products. J. Biol. Phys. 41: 303--311.

Lomakina, K. and K. Mikova. 2006. A study of the factors affecting the foaming properties of egg white - a review. Czech J. Food Sci. 24: 110-118.

Lucisano, M., A. Hidalgo, E. M. Comelli and M. Rossi. 1996. Evolution of chemical and physical albumen characteristics during the storage of shell eggs. J. Agric. Food Chem. 44: 1235-1240.

Mansoori, B., M. Modirsanei and M. M. Kiaei. 2008. Influence of dried tomato pomace as an alternative to wheat bran in maize or wheat based diets, on the performance of laying hens and traits of produced eggs. Iran. J. Vet. Res. 9(4): 341-346.

Martz, F., L. Jaakola, R. Julkunen-Tiitto and S. Stark. 2010. Phenolic composition and antioxidant capacity of bilberry (Vaccinium myrtillus) leaves in Northern Europe following foliar development and along environmental gradients. J. Chem. Ecol. 36: $1017-1028$
Mechikova, G. Y., A. S. Kuzmich, L. P. Ponomarenko, A. I. Kalinovsky, T. A. Stepanova, S. N. Fedorov and V. A. Stonik. 2010. Cancerpreventive activities of secondary metabolites from leaves of the bilberry Vaccinium smallii A. Gray. Phytother. Res. 24: $1730-1732$.

Mine, Y. 2002. Recent advances in egg protein functionality in the food system. World's Poultry Sci. J. 58: 31-39.

Minelli, G., F. Sirri, E. Folegatti, A. Meluzzi and A. Franchini. 2007. Egg quality traits of laying hens reared in organic and conventional systems. Ital. J. Anim. Sci. 6: 728-730.

Mironeasa, S., G. G. Codină and C. Mironeasa. 2012. The effects of wheat flour substitution with grape seed flour on the rheological parameters of the dough assessed by Mixolab. J. Text. Stud. 43: 40-48.

Nour, V., T. D. Panaite, P. A. Vlaicu and A. R. Corbu. 2018. Responses of laying hens to the simultaneous dietary supplementation with flaxseed and dried tomato by-products. J. Biotechnol. 280 : S57.

Nour, V., I. Trandafir and S. Cosmulescu. 2012. HPLC determination of phenolic acids, flavonoids and juglone in walnut leaves. J. Chromatogr. Sci. 51: 883-890.

Nuernberg, K., G. Nuernberg, A. Priepke and D. Dannenberger. 2015. Sea buckthorn pomace supplementation in the finishing diets of pigs- are there effects on meat quality and muscle fatty acids? Arch. Anim. Breed. 58: 107-113.

Pereira, J. A., I. Oliveira, A. Sousa, P. Valentão, P. B. Andrade, I. C. Ferreira, F. Ferreres, A. Bento, R. Seabra and L. Estevinho. 2007. Walnut (Juglans regia L.) leaves: Phenolic compounds, antibacterial activity and antioxidant potential of different cultivars. Food Chem. Toxicol. 45: 2287-2295.

Rao, M. A. 2013. Rheology of Fluid, Semisolid, and Solid Foods: Principles and Applications. Springer Science and Business Media., Berlin.

Sakanaka, S., K. Kitahata, T. Mitsuya, M. A. Gutierrez and L. R. Juneja. 2000. Protein quality determination of delipidated egg-yolk. J. Food Compos. Anal. 13: 773-781.

Scott, T. A. and F. G. Silversides. 2000. The effect of storage and strain of hen on egg quality. Poult. Sci. 79: 1725--1729.

Severa, L., Š. Nedomová and J. Buchar. 2010. Influence of storing time and temperature on the viscosity of an egg yolk. J. Food Eng. 96: 266-269.

Silva, S., L., Gomes, F., Leitao, A. V. Coelho and L. V. Boas. 2006. Phenolic compounds and antioxidant activity of Olea europaea L. fruits and leaves. Food Sci. Tech. Int. 12: 385-395.

Silversides, F. G. and T. A. Scott. 2001. Effect of storage and layer age on quality of eggs from two lines of hens. Poult Sci. 80: 1240-1245.

Simeonovova, J., K. Mikova, I. Ingr and S. Kubisova. 2003. Technology of Poultry, Eggs, and Minor Animal Products (in Czech). MZLU Brno: , Brno, Czech Republic.

Sokołowicz, Z., J.Krawczyk and M. Dykiel. 2018. Effect of alternative housing system and hen genotype on egg quality characteristics. Emir. J. Food Agric. 30(8): 695-703.

Souza, P. M. and A. Fernández. 2013. Rheological properties and protein quality of UV-C processed liquid egg products. Food Hydrocolloids 31: 127-134.

Stadelmann, W. J. and O. J.Cotterill. 1995. Egg Egg Science Science and and Technology. . The The Harworth Harworth Press: , Binghamton.

Steffe, J. F. 1996. Rheological Methods in Food Process Engineering (. 2nd ed.), East Lansing, Ml: Freeman Press Inc., East Lansing, MI.

Świątkiewicz, S., A., Arczewska-Włosek, J. Krawczyk, W. Szczurek, M. Puchała and D. Józefiak. 2018. Effect of selected feed 
additives on egg performance and eggshell quality in laying hens fed a diet with standard or decreased calcium content. Ann. Anim. Sci. 18: 167-183.

Tilki, M. and S. Inal. 2004. Quality traits of goose eggs. 2. Effects of goose origin and storage time of eggs. Arch. Für Geflugelk 68: 230--234.

Velez-Ruiz, J. 2002. Relevance of Rheological Properties in Food Process Engineering. In: Engineering and Food for the 21st
Century: . CRC Press LLC, United States..

Walsh, T. J., R. E. Rizkand J. Brake. 1995. Effects of temperature and carbon dioxide on albumen characteristics, weight loss, and early embryonic mortality of long stored hatching eggs. Poult. Sci. 74: 1403--1410.

WuWu, L., X. Huang, K. Shi and R. Tan. 2009. Bioavailability comparison of free and esterified lutein for layer hens. Braz. J. Poultry Sci. 11(2): 95-98. 